\title{
The Effectiveness of Branchless Banking on Banking Agents: A Case Study in the City of Bima
}

\author{
Puji Muniarty* \\ Institute of Economic Science of Bima \\ Bima,Iindonesia \\ puji.stiebima@gmail.com \\ Aliah Pratiwi \\ Institute of Economic Science of Bima \\ Bima,Iindonesia \\ aliahpratiwi@ymail.com
}

\author{
Nurhayati Nurhayati \\ Institute of Economic Science of Bima \\ Bima,Iindonesia \\ nurhayati.stiebima@gmail.com \\ Ita Purnama \\ Institute of Economic Science of Bima \\ Bima,Iindonesia \\ ita123purnama@gmail.com
}

\begin{abstract}
This study aims to determine the effectiveness of branchless banking services on banking agents (A Case study in City of Bima). This research is a descriptive research in which a conclusive qualitative approach with descriptive surveys is used. The populations in this research were all 163 BNI 46 (National Bank of Indonesia) agents in the city of Bima. 8 BNI 46 agents were purposively taken as the sample of this research in which there were 80 respondents that use Branchless Banking Service. This research was conducted for 3 months starting from May to July 2019 . In order to analyze the data, validity test, reliability test and one sample t-test were used. The validity test indicates that all items in question are valid because the total value of Corrected Item Correlation is higher than 0.3 while the Reliability test is higher than the Cronbach's Alpha value which is $0,817>0.60$ that means it is reliable. The t-test is greater than the value of t-table $(67.912>1.99)$ which means the branchless banking service is very effective.
\end{abstract}

Keywords - effectiveness, branchless banking, banking agents

\section{INTRODUCTION}

The financial supervision authority provides the right to perform basic banking services such as savings, lending or credit, and various other financial services. Thus, banks as financial institutions must be more creative in providing a variety of products in the form of financial management services. Bank services are very important in improving the economic level of the community which is realized by increasing public awareness in using their funds wisely. In order to do so, the banks need to utilize the facilities provided whether it is deposits, loans or other services that are needed by the community, especially for those who are far from financial services.

Banking financial services are also known as financial inclusion. In this case, financial inclusion can be interpreted as achieving the situation of unbanked people, especially low-income people, so that they can use simple and easy-to-understand banking financial services. Thus, low-income people can help the community to improve their welfare and help the government to reduce poverty. Financial inclusion realizes the purpose of accessing financial services through branchless banking programs. Branchless banking can be defined as "a distribution channel strategy used for delivering financial services without relying on Bank branches" or in other words a banking innovation where the Bank carries out financial services outside the branch office. These activities can be carried out by involving agents and relying on information and communication technology to send transaction details as a form of the accountability of the agents to the banks and the public [1].

The role of agents as an extension of the branchless banking program effectively and widely connects unbanked and underbanked people so that these people have the opportunity to earn a good living and help banking institutions, non-banking institutions and the government in reaching the poor with micropayment, in addition this program can help in financial accessing by using roll-out costs with a physical presence and the costs of low-value transaction security such as cash transactions, account registration, financing for micro customers, microinsurance and other online financial products via mobile phones. This will result in a sharp reduction of costs, create opportunities to significantly increase the population share with access to formal financing and provide opportunities for the lay-banking community to obtain financial services, especially in rural areas in which many poor people live. However, the current conditions, especially in the city of Bima, there are still some levels of society that do not understand branchless banking services, this is showed by the fact that some people prefer the conventional way that is by going to tellers or using ATM facilities.

Based on the description above, the following question was raised that is "How Effective is Branchless Banking Services on Banking Agents? (A case study in the city of Bima). This study aims to determine the effectiveness of Branchless Banking Services for Banking Agents (Study in the city of Bima.

\section{LITERATURE REVIEW}

\section{A. Branchless Banking}

The branchless banking can be defined as a form of linking or providing financial services to the community located outside the branches of traditional banks by using information technology (ICT) [2]. The objectives of branchless banking are: (1) to provide financial products 
that are simple, easy to understand and following the needs of the community that have not been able to reach financial services and (2) with the increasing number of members of various community groups in various regions of Indonesia that use financial/banking services, it is hoped that economic activities of the community may run much more smoothly so that it encourages economic growth and equitable development among regions in Indonesia, especially between villages and cities.

\section{B. The Agent of Branchless Banking}

Based on the rules of Financial Services Authority of 2014, an agent is a party (individual and/or legal entity) that cooperates with the bank that conducts branchless banking and becomes an arm of the bank to provide banking services and other financial services as promised to the public in the framework of financial inclusion.

\section{The Model of Branchless Banking}

\section{1) Bank-Led Model}

In this model, banks use telecommunications services, agents or even both to serve the needs of the community. According to Lyman the Bank creates financial products and services, but the distribution of these products and services is done through retail agents that manage customers [3]. Banks play a full role in this model starting from the initial licensing process, the implementation of operational activities, financial management and system management. Meanwhile, telecommunications companies play a role in providing networks to conduct transactions in banking services. The banking considerations of this model are proximity, speed and low cost. In this model, the banks use the services of telecommunications companies as agents. As an example, countries that have applied this model are Brazil and India.

\section{2) Telco-Led Model}

Technological companies provide the most basic banking services without involving banks in business processes, in this case the banks are only supporting. The Telco-Led Model is a model of branchless banking in which all licensing and operational processes are carried out by non-bank institutions. The institution provides the most basic banking services and banks are not directly involved in business operations. The customer does not have a contractual relationship with the bank and the product offered is electronic money (e-money). E-money is the value of money that is measured in currencies that are stored in electronic form and can be used to make transactions accepted by entities rather than issuers [4].

\section{Effectiveness}

Effectiveness is the degree to which something is successful in producing a desired result. In this case, it can be seen from the results, objectives, or consequences desired by the program activities that have been maximumly reached. Starawaji (2009) argues that effectiveness shows the degree to which goals occur. So, effectiveness is the effect caused by the existence of a certain activity to know the extent to which the level of success is achieved in every action that is done. Aras (2003) defines effectiveness as a condition in which the ability of a system is following the wishes of the user.

\section{E. Service Quality}

In companies engaged with services, especially banking services through clever behavior programs conducted by BNI 46 agents, competitive advantage is often sought in the form of superior service. In bank services, including clever behavior agents, which are bank extensions, the quality of the product measured is the quality of service. Parasuraman et al. (1990) defined product quality as a service received by consumers under consumer expectations for quality. In this case, to find out whether the quality of service received by consumers is following consumer expectations or not, the researchers used questionnaires and interviews about consumer complaints with several dimensions that affect service quality, namely tangible, reliability, responsiveness, assurance and empathy.

In companies engaged with services, especially banking services, through the Branchless Banking program conducted by the agents of $B N I 46$, competitive advantage is often sought in the form of superior service. In bank services, including the agents of branchless banking, the measurement of product quality is the quality of service. Parasuraman et al. (1990) defines product quality as a service received by consumers following consumer expectations for quality. In this case, it is intended to find out whether the quality of service received by consumers is under consumer expectations which is obtained through questionnaires or interviews regarding consumer complaints with several dimensions that affect service quality, namely tangible, reliability, responsiveness, assurance and empathy.

\section{RESEARCH METHOD}

The research was conducted on the agents of BNI 46 across the city of Bima for 3 months starting from May to July 2019. The data used were qualitative data, which were primary data sources, the approach was carried out with a conclusive qualitative approach with descriptive surveys involving obtaining samples from several respondents through a questionnaire using a Likert scale and interviews. The population in this study was all the agents of BNI 46 in the city of Bima amounted 493 agents. Since the population was large, 8 agents of BNI 46 were purposively chosen as the samples of this research. The purposive sampling technique was used to focus on agents that can provide permission and information for this research. A number of 10 respondents that use branchless banking were taken from each agent of BNI 46 and thus, the total number of respondents for this research is 80 respondents.

The validity test, reliability test and one sample t-test were used. A validity test is used to measure the validity of the questionnaire. A validity test was done by a one-shot method wherein the measurement with this method was only done once. If each statement is greater than 0.30 or > 0.30 then the item in question is considered valid. The reliability test was determined by Cronboch's Alpha by making a reliable instrument in which the results of the test are considered reliable if its Cronbach's Alpha coefficient is greater than 0.06 or $>0.60$. One-sample t-test was used to measure the level of effectiveness of branchless banking on banking agents in the city of Bima. 


\section{RESULTS AND DISCUSSION}

\section{A. Validity and Reliability Test}

Based on the results of the validity and reliability tests, all items of questions are valid and reliable. It can be seen from the following table:

TABLE I. THE RESULT OF RELIABILITY TEST IN EFFECTIVENESS OF BRANCHLESS BANKING

\begin{tabular}{|c|c|}
\hline \multicolumn{2}{|c|}{ Reliability Statistics } \\
\hline Cronbach's Alpha & $\mathrm{N}$ of Items \\
\hline .817 & 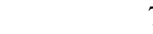 \\
\hline
\end{tabular}

Based on Reliability Statistics above Cronbach's Alpha value of 0,817 which means that the question raised that is a dimension of the Effectiveness of Branchless Banking is reliable.

TABLE II. RESULTS OF VALIDITY TEST IN EFFECTIVENESS OF BRANCHLESS BANKING

\begin{tabular}{|r|r|r|r|r|}
\hline \multicolumn{5}{|c|}{ Item-Total Statistics } \\
\hline & $\begin{array}{c}\text { Scale Mean if } \\
\text { Item Deleted }\end{array}$ & $\begin{array}{c}\text { Scale Variance } \\
\text { if Item Deleted }\end{array}$ & $\begin{array}{c}\text { Corrected Item- } \\
\text { Total Correlation }\end{array}$ & $\begin{array}{c}\text { Cronbach's } \\
\text { Alpha if Item } \\
\text { Deleted }\end{array}$ \\
\hline P1 & 26.22 & 10.430 & .505 & .801 \\
\hline P2 & 26.30 & 10.972 & .376 & .818 \\
\hline P3 & 26.42 & 9.032 & .638 & .777 \\
\hline P4 & 26.41 & 9.385 & .622 & .781 \\
\hline P5 & 26.52 & 9.139 & .623 & .780 \\
\hline P6 & 26.37 & 9.427 & .569 & .790 \\
\hline P7 & 26.39 & 9.506 & .553 & .793 \\
\hline
\end{tabular}

Based on the table above, all the question items are valid because the value of the Corrected-item totalCorrelation is greater than 0.3

TABLE III. HYPOTHESIS TEST, ONE-SAMPLE T-TEST

\begin{tabular}{|c|c|c|c|c|c|c|}
\hline \multicolumn{7}{|c|}{ One-Sample Test } \\
\hline & \multicolumn{6}{|c|}{ Test Value $=3.6$} \\
\hline & \multirow[t]{2}{*}{$\mathrm{t}$} & \multirow[t]{2}{*}{ df } & \multirow[t]{2}{*}{$\begin{array}{l}\text { Sig. (2- } \\
\text { tailed) }\end{array}$} & \multirow[t]{2}{*}{$\begin{array}{c}\text { Mean } \\
\text { Difference }\end{array}$} & \multicolumn{2}{|c|}{$\begin{array}{l}95 \% \text { Confidence } \\
\text { Interval of the } \\
\text { Difference }\end{array}$} \\
\hline & & & & & Lower & Upper \\
\hline $\begin{array}{c}\text { Effectiveness of } \\
\text { Branchless } \\
\text { Banking Services }\end{array}$ & 65.913 & 79 & .000 & 26.375 & 25.58 & 27.17 \\
\hline
\end{tabular}

Output SPSS V.16

This result is also supported after researchers conducted a hypothesis test in which the value of t-test is greater than the value of t-table $(65.913>1.99)$, in decision making, if t-test $>\mathrm{t}$-table then Ho is rejected, therefore $\mathrm{Ha}$ is accepted which means that the branchless banking service is very effective

\section{CONCLUSION}

Based on the hypothesis, the branchless banking on Banking Agents is very effective.

\section{REFERENCES}

[1] A. Kusumawati, "Tanggung Jawab Agen Kepada Nasabah Penyimpan dan Simpanannya terhadap Layanan Perbankan Branchless Banking (Ditinjau dari Peraturan Otoritas Jasa Keuangan Nomor 19/pojk. 03/2014 Tanggal 19 November 2014 Tentang Layanan Keuangan tanpa Kantor dalam Rangka K,” Kumpul. J. Mhs. Fak. Huk., 2015.

[2] Y. Purwati and R. Franksiska, "Strategi Peningkatan Kemampuan Adopsi Teknologi Branchless Banking untuk Memperluas Inklusi Keuangan di Masyarakat Pedesaan," 2014.

[3] T. Lyman, G. Ivatury, and S. Staschen, "Use of agents in branchless banking for the poor: rewards, risks, and regulation," Focus note, vol. 38, 2006.

[4] B. Indonesia, "Penerapan Branchless Banking di Indonesia," Direktorat Penelit. dan Pengaturan Perbankan. Prelim. Study. Jakarta, 2011. 